\title{
Exploratory Research on Campus Online Loan Behavior of College Students
}

\author{
Meng-Ran LI, Cheng-Yue YIN \\ School of Business \\ Northeast Normal University \\ Changchun, China \\ E-mail: 1872458810@qq.com,yincy653@nenu.edu.cn
}

\begin{abstract}
As the number of campus online loan platforms increases, there are more and more problems in campus online loan behavior of college students. This study aims to analyze campus online loan behavior of college students. The research results show that college students with strong delay of gratification have a lower degree of irrational consumption psychology and irrational consumption behavior. Irrational consumption psychology is significantly related to irrational consumption behavior. The delay of gratification, irrational consumption psychology and irrational consumption behavior of college students are significantly correlated with campus online loan behavior of college students.
\end{abstract}

Keywords-Campus online loan behavior; Delay of gratification; Irrational consumption psychology; Irrational consumption behaviors

\section{INTRODUCTION}

In 2016, a student from Henan University of Animal Husbandry \& Economy leaped to death due to the inability to repay campus online loan. Since then, campus online loan has been valued by the society. Campus online loan platforms mainly include three types: 1. installment shopping platform for college students; 2. P2P online loan platform; 3. credit loan services provided by traditional e-commerce platforms such as Jingdong and Alibaba. The data of WWW.WDZJ.COM show, there is only 1 online loan platform in 2007, while the number of campus online loan platforms had reached 2281 by March 2017. Numerous problems occur inevitably under such explosive growth process. For example, most platforms have insufficient risk control ability. Besides, the bad credit loan rate of some platforms is too high, and there is usurious loan suspicion.

Since online loan has risen in recent two years, domestic researches on it are just a few and mainly focus on external factors, without relevant empirical study. Most researches are social investigations for online behavior, theoretical analysis of psychology and suggestions on online loan. Starting from two external factors: irrational consumption psychology and delay of gratification, this paper probes into the reasons for online loan behavior of college students and conducts empirical study, in the hope of well guiding online loan behavior of college students and their irrational consumption behavior.

This study was supported by the National Social Science Foundation of C hina (No. 15BGL092).

\section{THEORETICAL BASIS}

\section{A. Delay of gratificatione}

Delay of gratification was first proposed by Mischel [1] Mischel thought, delay of gratification refers to "the selection orientation of giving up immediate gratification for the more valuable long-term result", and it is related to self-control and is the manifestation of psychological maturity. In Mischel's early research, classical children's ability test experiment for delay of gratification was designed, and new elements were added continuously to observe children's responses in different situations and the influence of waiting strategy on waiting time. Metcalfe and Mischel [2] put forward dual-system launch model theory. The model includes "hot" and "cold" systems. "Hot" system makes responses to impulsion and can gain immediate gratification more easily. "Cold" system is more beneficial to target keeping and gaining delay of gratification. Mischel's later research on delay of gratification shows, the children with strong ability for delay of gratification own stronger social competitiveness after they grow up and can better cope with pressure and fatigue. Delay of gratification has great significance for individuals.

\section{B. Irrational consumption psychology}

\section{1) Definition of irrational consumption psychology}

Shi Yingling considered, consumption psychology refers to consumer's psychological activity in the purchasing process. It is a response of synthesizing consumption object and consumption needs. Xu Ping defined consumption psychology as the psychological process of adjusting one's consuming behavior under the general social consumption environment. Under the dominance of consumption psychology, consuming behavior not just reflects the influence of external factors, but also reflects consumer's individual traits and psychological features. Shen Yanting thought, college students have strong self-esteem demand, so they may easily have conspicuous consumption and comparison consumption in order to establish self-esteem and other-esteem system. Meanwhile, in her opinion, comparison psychology of college students is reflected into two aspects: conformity and difference seeking. In other words, college students also hope their consumption is unique while accepting the things accepted by most people. In conclusion, such mental disposition deviating from utility maximization consumption decision is defined as irrational consumption psychology. 


\section{2) Factors affecting irrational consumption psychology}

There are many factors influencing consumption psychology of college students. Domestic and overseas researchers mainly focus on school, society and family. In terms of school-related factors, Zhang Qian believed university management system is an important factor influencing consumption psychology of college students. College environment is a catalyst of irrational consumption behavior. Colleges generally lack education on consumption psychology and consuming behavior. With regard to family factors, Zhao Jianhui held that, daily consumption behavior of a family will shape the consumption behavior of children. Parents' consumption psychology will directly influence children's consumption psychology. Parents' economic supply for children will also influence their consumption psychology. If parents blindly meet children's consumption without condition, this will increase their irrational consumption behavior.

\section{Irrational consumption behavior}

\section{1) Definition of irrational consumption behavior}

Kahneman first defined irrational behavior in 1979: based on inconsistent individual preference, individual consumption option does not follow the principle of utility maximization. Based on Kahneman, Simon proposed in 1956 that, irrational behavior is a conditioned reflex process. In his opinion, consumers use acceptable satisfaction to replace maximum satisfaction. Chinese scholar Huang Shoukun proposed, irrational consumption behavior is "unreasonable consumption decision made by the consumer under the influence of irrational factors", and does not pursue utility maximization and blind consumption. In one word, irrational consumption behavior is the dissimilation of consumption behavior and influences people's living quality. College students mainly show conformity consumption, impulsive consumption, blind consumption and excessive consumption, etc.[3].

\section{2) Factors affecting irrational consumption behavior}

Herbert A.Simon [4] proposed that, customers are influenced by numerous limiting factors in the buying process, so it is normal for them to show irrational consumption behavior. Lea Gulko considered that, limiting factors mainly include condition uncertainty, information asymmetry and the limit of income level and purchasing power. In the view of Tauseef Ahmad, individual traits and external stimulating factors are also the key factors influencing irrational consumption behavior [5]. The customer group with strong hedonic psychology, comparison psychology, poor self-control ability and high income level is the main group of irrational consumption behavior. Product factors (product shape and price, etc.), environmental factors (product display and background music of shop, etc.) and situational factors (customer's emotion and shopping time, etc.) are external stimulating factors influencing irrational behavior.

\section{RESEARCH DESIGN AND RESEARCH METHOD}

\section{A. Purpose of research}

With the development of times, college students are faced with more and more lures. It is urgent to study the factors influencing consumption behavior and online loan behavior of college students. The research of Bembenutty [6] shows, the students with the strong ability of delay of gratification will use more resource management strategies and better wait for longterm value. Thus, the ability of delay of gratification is vital for shaping rational consumption behavior of college students. The research of $\mathrm{Li} \mathrm{Han}$ on irrational consumption psychology shows that, the college students with irrational consumption psychology more easily have excessive consumption behavior, while online loan behavior is a manifestation of excessive consumption behavior. On this basis, the following hypotheses are put forward:

H1: There is correlation among delay of gratification, irrational consumption psychology, irrational consumption behavior and campus online loan behavior.

H2: Delay of gratification, irrational consumption psychology, irrational consumption behavior have significant prediction effect on campus online loan behavior.

\section{B. Objects of study}

The main objects are the students of key and ordinary universities. There were 209 effective samples, including 118 male students $(56.5 \%)$ and 92 female students (43.5\%). There were 155 students from key universities $(74.2 \%)$, 51 students from ordinary universities $(24.4 \%)$ and 3 students from junior colleges $(1.4 \%)$.

\section{Research methods}

In this study, the data were collected by questionnaire survey. The questionnaires were mainly handed out in Jilin University, Changchun University of Science and Technology, and Changchun University. Delay of gratification questionnaire was prepared by Ray [7]. The questionnaire includes 12 items. Three-point scoring method was adopted. Internal consistency coefficient of the scale is 0.72 .in view of the problems existing in the translation process, the reliability can be accepted. In the compatible validity test with domestic existing academic delay of gratification scale, correlation coefficient was 0.28 , which is significant at the level of 0.05 . Since academic delay of gratification is a dimension of general delay of gratification, validity of the questionnaire can be accepted. Irrational psychology questionnaire and irrational behavior questionnaire were prepared by Li Han. In this study, some questions were deleted according to actual situations. The internal consistency coefficient of irrational consumption psychology was 0.79 , and internal consistency coefficient of irrational consumption behavior was 0.71 . 


\section{RESEARCH RESULTS AND DISCUSSIONS}

A. Analysis of current situations of delay of gratification, irrational consumption psychology and irrational consumption behavior

1) Variation analysis of delay of gratification, irrational consumption psychology and irrational consumption behavior

Since there were only 3 data of junior college students, junior college indexes were eliminated in school factor study, and only the differences between key and ordinary university students were analyzed. The research results show that, delay of gratification has no significant difference in four demographic variables: gender $(\mathrm{t}=1.114, \mathrm{p}>0.05)$, address $(\mathrm{t}=0.764, \mathrm{p}>0.05)$, school $(\mathrm{t}=-1.288, \mathrm{p}>0.05)$ and only child $(\mathrm{t}=1.777, \mathrm{p}>0.05)$. Irrational consumption psychology of college students has no significant difference in three demographic variables: gender, school and only child. When address serves as the variable, irrational consumption psychology of college students presents significant difference at the level of $0.01(\mathrm{t}=-2.910, \mathrm{p}<0.01)$. Irrational consumption behavior of college students has no significant difference in three demographic variables: gender, school and only child. When address serves as the variable, irrational consumption behavior of college students presents significant correlation at the level of $0.05(\mathrm{t}=-2.532, \mathrm{p}<0.05)$. The mean value of irrational consumption behavior of college students living in rural area is $27.13(\mathrm{SD}=3.72)$. The mean value of irrational consumption behavior of college students living in urban area is 29.64 $(\mathrm{SD}=4.38)$. The data indicate that, irrational consumption behavior of college students living in urban area is more obvious.

2) Differences in delay of gratification, irrational consumption psychology and irrational consumption behavior

The researches of Bembenutty and Silverman Irwin W [8] show female ability of delay of gratification is stronger than male ability of delay of gratification on the whole. The study of $\mathrm{Hu}$ Fengjiao also verifies significant difference of delay of gratification in gender factor. Different from predecessors' results, the research results in this paper show delay of gratification is most significant in gender factor. This may be because the difference between the male and the female becomes smaller and smaller. Traditional cognition of gender is no longer applicable. This study indicates that, irrational consumption psychology and behavior of college students living in urban area are significantly different from that of college students living in rural area. The results are different from predecessors' results. Consumption psychology of college students living in rural area is more rational than that of college students living in urban area. This may be because college students from rural area can better understand their parents' hardships, and their consumption psychology and behavior are more pragmatic and rational. College students from urban area may generate more irrational consumption psychology and behaviors, because they are influenced by comparison and enjoyment mood in urban life.

\section{B. Study on relationship among delay of gratification, irrational consumption psychology, irrational consumption behavior and campus online loan behavior}

1) Correlation analysis of delay of gratification, irrational consumption psychology, irrational consumption behavior and campus online loan behavior

The research results show that, delay of gratification presents moderate negative correlation with irrational consumption psychology at the level of $0.01 \quad(\mathrm{r}=-0.47)$, and moderate negative correlation with irrational consumption behavior ( $\mathrm{r}=-$ 0.55). Irrational consumption psychology and irrational consumption behavior present moderate positive correlation y at the level of $0.01(\mathrm{r}=0.68)$. Campus online loan behavior presents extremely significant $(\mathrm{p}<0.05)$ low negative correlation with delay of gratification $(r=-0.17)$, significant $(\mathrm{p}<0.01)$ low correlation with irrational consumption psychology, and significant $(\mathrm{p}<0.01)$ extremely low positive correlation with irrational consumption behavior $(\mathrm{r}=0.18)$.

2) Regression analysis of influences of delay of gratification, irrational consumption psychology and irrational consumption behavior on campus online loan behavior

The research results show that, delay of gratification, irrational consumption psychology and irrational consumption behavior have significant prediction effect on campus online loan behavior of college students. Delay of gratification has significant prediction effect on irrational consumption psychology and irrational consumption behavior, as shown in Tab.1, Tab.2 and Tab.3.

TABLE I. REGRESSION ANALYSIS OF INFLUENCES OF DELAY OF GRATIFICATION, IRRATIONAL CONSUMPTION PSYCHOLOGY AND IRRATIONAL CONSUMPTION BEHAVIOR ON CAMPUS ONLINE LOAN BEHAVIOR

\begin{tabular}{|c|c|c|c|c|}
\hline \multirow{2}{*}{ Independent variable } & \multicolumn{4}{|c|}{ Dependent variable: campus online loan behavior } \\
\hline & Standardized coefficient & $S E$ & $t$ & $\boldsymbol{P}$ \\
\hline Delay of gratification & -0.267 & 0.008 & -3.195 & 0.002 \\
\hline Irrational consumption psychology & 0.268 & 0.003 & 4.007 & 0.000 \\
\hline Irrational consumption behavior & 0.268 & 0.004 & 3.997 & 0.000 \\
\hline
\end{tabular}


TABLE II. REGRESSION ANALYSIS OF INFLUENCE OF DELAY OF GRATIFICATION ON IRRATIONAL CONSUMPTION PSYCHOLOGY

\begin{tabular}{|c|c|c|c|c|}
\hline \multirow{2}{*}{ Independent variable } & \multicolumn{3}{|c|}{ Dependent variable: irrational consumption psychology } \\
\cline { 2 - 5 } & Standardized coefficient & $S E$ & $t$ & $\boldsymbol{T}$ \\
\hline Delay of gratification & -0.468 & 0.146 & -7.622 & 0.000 \\
\hline
\end{tabular}

TABLE III. REGRESSION ANALYSIS OF INFLUENCE OF DELAY OF GRATIFICATION ON IRRATIONAL CONSUMPTION BEHAVIOR

\begin{tabular}{|l|l|l|l|l|}
\hline \multirow{2}{*}{\multicolumn{1}{c|}{ Independent variable }} & \multicolumn{3}{|c|}{ Dependent variable: irrational consumption behavior } \\
\cline { 2 - 5 } & & Standardized coefficient & \multicolumn{2}{c|}{$S E$} \\
\hline Delay of gratification & -0.55 & 0.104 & -9.465 \\
\hline
\end{tabular}

3) Relationship among delay of gratification, irrational consumption psychology, irrational consumption behavior and campus online loan behavior

According to the data analysis results, we can know that, the college students with strong ability of delay of gratification often have more rational consumption psychology and consumption behavior, because the college students with strong ability of delay of gratification can better bear immediate desire for the long-tern benefit. The college students with strong ability of delay of gratification will reduce irrational consumption psychology. Irrational consumption psychology represents a consumption idea which will influence individual behavior, thus decreasing irrational consumption behavior. Regression analysis results also show delay of gratification can to certain degree predict irrational consumption psychology and irrational consumption behavior. According to research data analysis results, campus online loan behavior is significantly correlated with delay of gratification, irrational consumption psychology and irrational consumption behavior. Delay of gratification, irrational consumption psychology and irrational consumption behavior have significant prediction effect on campus online loan behavior. This indicates that, campus online loan behavior of college students is influenced by delay of gratification, irrational consumption psychology and irrational consumption behavior.

\section{Status analysis of campus online loan behavior}

\section{1) Descriptive statistics of purposes of online loan funds}

The statistics was made for fund purpose of 69 college students with online loan behavior. The results show that, the funds from online loan were mainly used to purchase electronic products $(\mathrm{N}=30)$ and clothes $(\mathrm{N}=26)$. Some female students purchased cosmetics. 22 college students used the money for entertainment. 21 college students used the money for diner party. 20 college students used the money for study. 9 college students used the money for travelling.

2) Correlation analysis of online loan behavior and living expenses of college students

The results show that, the correlation coefficient of online loan behavior and living expenses is 0.284 , significant at the level of 0.01 . This means online loan behavior changes with the living expenses of college students. Their online loan behavior has low correlation with their living expenses.
3) Discussion on online loan behavior of college students

Among 209 samples, 69 college students had online loan behavior. Based on the statistics of fund purposes of 69 college students with online loan behavior, the proportion of college students using the fund in study is greater than the proportion given by the predecessors, so the real situation cannot be reflected. Besides, the statistical results indicate that, the money from online loan is mainly used to buy electronic products $(\mathrm{N}=30)$ and clothes $(\mathrm{N}=26)$. The number of students using the money for entertainment and dinner party is also large. This result is consistent with the predecessors' results. This means the main consumption of college students is enjoyment.

The final statistical result shows, online loan behavior and living expenses present significant extremely low correlation. This means living expenses of college students have certain correlation with their online loan behavior. But according to the total research results, online loan behavior is more related to individual traits.

\section{CONCLUSION}

Main conclusions are as follows:

Difference examination result shows that, the score of irrational consumption psychology and irrational consumption behavior of rural college students is lower than that of urban college students. This means consumption psychology and consumption behavior of rural college students are more rational. Correlation analysis result shows that, the college students with strong ability of delay of gratification have lower degree of irrational consumption psychology and irrational consumption behavior. Irrational consumption psychology and irrational consumption behavior are of irrational consumption psychology and irrational consumption behavior. In addition, delay of gratification, irrational consumption psychology and irrational consumption behavior present significant low correlation with campus online loan behavior of college students. Regression analysis result shows that, delay of gratification, irrational consumption psychology and irrational consumption behavior have significant prediction effect on campus online loan behavior of college students. The ability of delay of gratification has significant prediction effect on irrational consumption psychology and irrational consumption behavior. Online loan behavior has significant low correlation with living expenses. 
Main defects of this study include the following. Firstly, the survey of technical colleges is insufficient, and the survey of senior college students is insufficient. The representativeness of sample is poor. Thus, the research in the aspects of school and grade is not ideal. Secondly, questionnaire collection result for family annual income and living expense source is not ideal. Most questions are left blank, and some questionnaires are filled in at random. Thus, the data could not be used, and relevant analysis could not be conducted. In the future study, effective means should be adopted for improvement.

\section{ACKNOWLEDGMENT}

This study was supported by the National Social Science Foundation of China (No. 15BGL092).

\section{REFERENCES}

[1] Mischel, W. (1974). Processes in delay of gratification. Advances in Experimental Social Psychology, 7, 249-292.

[2] Metcalfe, J., \& Mischel, W. (1999). A hot/cool-system analysis of delay of gratification: dynamics of willpower. Psychological Review, 106(1), 3.

[3] Liu Yu, (2015).Empirical Study on Irrational Consumption Behavior of College Students in Hunan Province [D]. University Of South China.(In Chinese)

[4] Sarasvathy, D. K., Simon, H. A., \& Lave, L. (2004). Perceiving and managing business risks: differences between entrepreneurs and bankers. Journal of Economic Behavior \& Organization, 33(2), 207-225.

[5] Ahmad, T. (2011). The impulse buying behavior of consumes for the fmcg products in jodhpur. Journal of Applied Sciences Research, 5(11), 1704-1710.

[6] Bembenutty, H., Karabenick, S. A., Mckeachie, W. J., \& Lin, Y. G. (1998). Academic delay of gratification as a volitional strategy. Academic Achievement, 10.

[7] John J. Ray, \& Jackob M. Najman. (1986). The generalizability of deferment of gratification. Journal of Social Psychology, 126(1), 117119.

[8] Silverman, I. W. (2003). Gender differences in delay of gratification: a meta-analysis. Sex Roles, 49(9-10), 451-463 